\title{
Pengaruh Blended Learning terhadap Kreativitas Mahasiswa Calon Guru di Universitas Negeri Medan
}

\author{
Nurhasanah Siregar $^{1, a)}$ dan Sri Lestari Manurung ${ }^{1}$ \\ ${ }^{1}$ Universitas Negeri Medan \\ Jl. Willem Iskandar Pasar V Kenangan Baru, Percut Sei Tuan, Deli Serdang, Indonesia, 20221 \\ a)nurhasanahsiregar@unimed.ac.id
}

\begin{abstract}
This study aims to determine the effect of blended learning strategies on the creativity of the preservice teachers. By a quantitative approach, the type used in this study is a quasi-experimental with pretestposttest control group design. The population in this study were pre-service teachers in semester VII of the Mathematics Education Study Program at Universitas Negeri Medan. The instrument has used a test in the form of essay tests of 5 items concerning creativity. The results of the study indicated that there were significant differences in the creativity of pre-services teachers who apply blended learning and direct learning. Thus, it could be concluded that blended learning gave effects of creativity.
\end{abstract}

Keywords: blended learning; creativity; pre-service teacher

\begin{abstract}
Abstrak. Penelitian ini bertujuan untuk mengetahui pengaruh strategi blended learning terhadap kreativitas mahasiswa calon guru. Pendekatan dalam penelitian ini menggunakan pendekatan kuantitatif jenis kuasi eksperimen dengan pretest-posttest control group design. Populasi dalam penelitian ini adalah mahasiswa calon guru semester VII Program Studi Pendidikan Matematika Universitas Negeri Medan. Adapun instrumen yang digunakan adalah tes berbentuk uraian sebanyak lima butir menyangkut kreativitas. Hasil dari penelitian menunjukkan bahwa terdapat perbedaan yang siginifikan terhadap kreativitas mahasiswa calon guru yang menerapkan blended learning. Dengan demikian, dapat disimpulkan bahwa blended learning berpengaruh terhadap kreativitas.
\end{abstract}

Kata kunci: blended learning, kreativitas, mahasiswa calon guru 


\section{PENDAHULUAN}

Tuntutan zaman saat ini tidak hanya pada kemampuan kognitif, namun juga keterampilan serta sikap yang baik agar tercipta keseimbangan antar kompetensi kognitif, psikomotorik dan afektif. Hal ini sesuai dengan tuntutan abad 21 yaitu manusia harus memiliki tiga jenis keterampilan yaitu: 1) keterampilan hidup dan keterampilan berkarir, 2) keterampilan belajar dan berinovasi serta 3) keterampilan memahami informasi media dan teknologi. Seseorang yang memiliki tiga keahlian tersebut dapat dipastikan memiliki kreativitas yang tinggi serta memiliki kemampuan bersaing (Wahyudi \& Winanto, 2018). Pada kenyataannya hasil dari indeks daya saing global manusia Indonesia menunjukkan penurunan dari tahun sebelumnya termasuk di dalamnya terkait dengan pendidikan (Schwab, n.d.).

Sebagai seorang guru, hal yang wajib dimiliki adalah kreativitas. Saat ini calon guru harus mampu menggabungkan pengetahuan dan kreativitas dalam menghadapi tantangan era revolusi industri 4.0 yang menekankan pada kreativitas dan teknologi. Hal ini sejalan dengan yang diungkapkan Abadzi et al. (2019) bahwa pada abad ini permintaan sangat tinggi terhadap pemikir kreatif. Pada dasarnya kreativitas memiliki arti yang cukup beragam. Pernyataan tersebut sesuai dengan yang diungkapkan Gomez (2007) bahwa kreativitas memiliki definisi beragam, misalnya ditinjau dari intelegensi seseorang. Dari studi literatur yang diungkap Gomez (2007), sejak tahun 1960-an kreativitas selalu dipertentangkan dengan intelegensi. Studi tersebut mengungkapkan bahwa adanya peningkatan intelegensi seseorang tidak menjamin peningkatan kreativitas orang tersebut, karena bahan yang diberikan untuk mengukur intelegensi dan kreativitas adalah berbeda. Kreativitas merupakan proses mental yang cukup tinggi yang terdiri dari kemampuan mendefinisikan ulang, menciptakan kembali, memproduksi ulang dengan pertimbangan yang cukup mapan, sehingga menjadikan sesuatu yang (Saparahayuningsih, 2010; Soleymanpour, 2014; Ulandari, Putri, Ningsih \& Putra, 2019). Beberapa ahli mengungkapkan bahwa kreativitas dapat diajarkan (Abadzi et al., 2019). Sejalan dengan waktu, level kreativitas yang diajarkan sejak dini dapat terus meningkat, yakni dimulai dari little-c, pro-c, sampai dengan big-c (Abadzi et al., 2019).

Salah satu usaha pengajar yang dapat dilakukan untuk menjadikan mahasiswa yang mengambil mata kuliah Permasalahan Pembelajaran Matematika Masa Kini (P2M2K) lebih kreatif adalah melalui strategi pembelajaran yang sesuai. Senada dengan pendapat Budiarti (2015) yang mengatakan bahwa model pembelajaran merupakan salah satu sarana yang dapat meningkatkan kreativitas. Strategi pembelajaran yang disajikan adalah pembelajaran yang bersentuhan dengan teknologi. Salah satu strategi pembelajaran tersebut adalah blended learning. Mengapa blended learning? Karena Universitas Negeri Medan (Unimed) selaku universitas yang mendukung perkembangan revolusi industri 4.0 mencoba menyediakan sistem pembelajaran online yang disebut dengan SIPDA. Blended learning adalah generasi ketiga dari pembelajaran jarak jauh. 
Blended learning pada penelitian ini bukanlah pembelajaran jarak jauh hanya memadukan antara pembelajaran online dengan tatap muka (face to face). Blended learaning mengacu pada desain ulang model pembelajaran dengan mengubah dari pengajaran yang berpusat pada guru menjadi berpusat pada siswa dan diharapkan menjadi lebih aktif. Blended learning juga diharapkan dapat meningkatkan interaksi antar pengajar-mahasiswa, mahasiswa-mahasiswa serta mampu memanfaatkan sumber-sumber dari internet dengan cara yang kreatif. Blended learning adalah inovasi dalam pembelajaran tradisional yang menggunakan teknologi berupa pembelajaran online dan offline (Thorne, 2003).

Peneliti menilai perlu untuk menerapkan strategi blended learning berbantuan SIPDA pada mata kuliah P2M2K. Tujuan penelitian ini adalah untuk mengetahui apakah strategi blended learning berbantuan SIPDA Unimed memberikan pengaruh yang signifikan terhadap kreativitas mahasiswa. Dengan adanya penelitian ini diharapkan memberikan manfaat (1) menghasilkan menghasilkan mahasiswa kreativitas yang tinggi, (2) menciptakan alternatif model pembelajaran yang inovatif, (3) membiasakan proses blended learning di kalangan mahasiswa dan dosen.

\section{METODE}

Pendekatan yang digunakan dalam penelitian ini adalah pendekatan kuantitatif dengan jenis penelitian eksperimen semu. Adapun desain yang digunakan adalah pretest-posttest control group. Penelitian dilaksanakan pada Program Studi Pendidikan Matematika di Unimed pada Semester Gasal Tahun Ajaran 2019/2020. Populasi dalam penelitian ini adalah seluruh mahasiswa Semester VII yang mengambil mata kuliah Permasalahan Pembelajaran Matematika Masa Kini. Teknik pengambilan sampel yang digunakan dalam penelitian ini adalah teknik cluster random sampling. Kelas-kelas secara acak diundi, lalu dari pengundian tersebut diperoleh kelas VII G sebagai kelas eksperimen yang menerapkan strategi blended learning berbantuan SIPDA Unimed dan kelas VII C sebagai kelas kontrol yang menerapkan pembelajaran langsung. Sebelum melakukan uji statistik, peneliti melakukan uji prasyarat terkait normalitas dan homogenitas dari data yang nilai ujian. Setelah memastikan bahwa data berdistribusi normal dan homogen, dilakukan uji-t untuk melihat pengaruh strategi pembelajaran terhadap kreativitas mahasiswa. Analisis data secara deskriptif dilakukan dengan membandingkan hasil tes kreativitas mahasiswa antara kelas eksperimen dan kelas kontrol, sedangkan analisis data secara inferensial dilakukan untuk melihat strategi pembelajaran yang berpengaruh terhadap kreativitasnya.

Dalam penelitian ini teknik yang digunakan untuk mengumpulkan data adalah dokumentasi dan tes. Dokumentasi yang digunakan dalam penelitian ini adalah daftar IPK. Data tersebut digunakan untuk uji keseimbangan. Metode tes dalam penelitian ini digunakan untuk mengetahui tingkat berpikir kreatif mahasiswa. Tes dalam penelitian ini berupa tes uraian sebanyak empat soal. 
Sebelum tes diberikan, dilakukan uji validitas dengan judgment ahli terkait face validity dan content validity. Ahli yang dimaksud adalah tiga orang dosen pada Program Studi Pendidikan Matematika. Dari tujuh soal tes berbentuk uraian, para ahli memberi saran berupa komentar untuk perbaikan instrumen yang akan digunakan untuk penelitian, sehingga dihasilkan empat soal yang valid.

\section{HASIL DAN PEMBAHASAN}

Dari penelitian yang dilakukan diperoleh data pretes dan postes terkait dengan kreativitas mahasiswa. Berikut ini disajikan secara deskriptif data pada masing-masing kelompok yang menerapkan strategi blended learning (eksperimen) dan pembelajaran langsung (kontrol).

Tabel 1. Statistik Deskriptif Kreativitas Mahasiswa Semester VII pada Mata Kuliah P2M2K

\begin{tabular}{ccccc}
\hline & \multicolumn{2}{c}{ Kelas Eksperimen } & \multicolumn{2}{c}{ Kelas Kontrol } \\
\cline { 2 - 5 } & Pretes & Postes & Pretes & Postes \\
\hline$N$ & 30 & 30 & 35 & 35 \\
\hline$X_{\min }$ & 10 & 20 & 11 & 15 \\
\hline$X_{\max }$ & 25 & 40 & 20 & 35 \\
\hline mean & 9,76 & 20,21 & 9,12 & 11,65 \\
\hline Standard Deviasi & 1,58 & 3,03 & 2,10 & 2,67 \\
\hline
\end{tabular}

Dari Tabel 1 terlihat bahwa skor pretes kedua kelompok tidak jauh berbeda dengan sebaran pada kelas kontrol yakni kelompok yang menggunakan pembelajaran langsung lebih beragam. Adapun pada akhir pembelajaran, skor postes, kelas eksperimen lebih tinggi 8,56 dibandingkan dengan kelas kontrol dengan sebaran yang lebih kecil. Secara sekilas dapat dikatakan bahwa kemampuan kreativitas mahasiswa yang menerapkan pembelajaran dengan strategi blended learing lebih baik daripada pembelajaran langsung. Namun demikian hasil tersebut tidak dapat dijadikan sebagai penarikan kesimpulan secara umum.

Untuk melakukan penarikan kesimpulan maka dilakukanlah uji statistik inferensial terkait hasil belajar mahasiswa (postes). Analisis data awal dari hasil pretes perlu dilakukan untuk mengetahui bahwa mahasiswa pada kedua kelompok memiliki kesamaan terkait kreativitasnya. Untuk itu dilakukan uji perbedaan kreativitas mahasiswa pada kelas eksperimen dan kelas kontrol yang dihitung dengan menggunakan data skor pretes. Adapun dari hasil pretest mahasiswa diketahui nilai rata-rata (mean) mahasiswa pada kelas eksperimen yaitu 54,310 dengan deviasi standar (SD) 12,923, sedangkan pada kelas kontrol mean 53,76 dengan SD sebesar 13,445. Selanjutnya yang menjadi fokus dalam penelitian ini adalah terkait dengan hasil postes kreativitas mahasiswa. Untuk melihat pengaruhnya, maka digunakan uji perbedaan dua rerata. Namun demikian, sebelum dilakukan uji perbedaan, dilakukan terlebih dahulu uji prasyarat yakni normalitas dan homogenitas yang dapat dilihat pada Tabel 2. 
Tabel 2. Hasil Uji Normalitas

\begin{tabular}{lcccc}
\hline & \multirow{2}{*}{ Kelas } & \multicolumn{3}{c}{ Shapiro-Wilk } \\
\cline { 2 - 5 } & Eksperimen & 0,879 & Df & Sig \\
\hline \multirow{2}{*}{ Kreativitas Mahasiswa } & Kontrol & 0,892 & 30 & 0,142 \\
\cline { 2 - 5 } & & & 35 & 0,301 \\
\hline
\end{tabular}

Lilliefors Significance Correction, $\alpha=0,05$

Hasil uji normalitas menunjukkan bahwa kedua kelas berdistribusi normal. Hal ini dapat dilihat dari nilai sig. kedua kelas lebih besar dari alpha yang telah ditentukan, yakni 0,05. Dengan demikian uji statistik inferensial yang digunakan menggunakan statistika parametrik. Adapun hasil uji homogenitas varians kedua kelompok pembelajaran dapat di lihat pada Tabel 3.

Tabel 3. Hasil Uji Homogenitas

\begin{tabular}{ccc}
\hline & \multicolumn{2}{c}{ Levene's test for Equality of Vairances } \\
\cline { 2 - 3 } & $\boldsymbol{F}$ & Sig \\
\hline Equal variance assumed & 1,195 & 0,227 \\
\hline Equal variance not assumed & & \\
\hline
\end{tabular}

Significance Correction, $\alpha=0,05$

Tabel 3 menunjukkan nilai sig. lebih besar dari alpha yang telah ditentukan. Dengan demikian kedua kelompok memiliki varians yang homogen. Selanjutnya uji statistika yang digunakan untuk melihat pengaruh pembelajaran adalah dengan melakukan uji perbedaan terhadap dua rerata hasil protes kreativitas mahasiswa pada kedua kelompok pembelajaran dengan menggunakan uji-t yang hasilnya dapat dilihat pada Tabel 4.

Tabel 4. Independent Sampel Test

\begin{tabular}{ccccc}
\hline & $\boldsymbol{t}$ & $\boldsymbol{D f}$ & Sig (2-tailed) & Std. Error Difference \\
\hline Kreativitas & 8,967 & 65 & 0,003 & 0,68975 \\
\hline
\end{tabular}

Significance Correction, $\alpha=0,05$

Dari Tabel 4. diperoleh informasi bahwa nilai sig sebesar 0,003 yang lebih kecil dari alpha yang telah ditentukan. Artinya dapat disimpulkan bahwa terdapat perbedaan yang siginifikan rerata kreativitas mahasiswa yang menerapkan strategi pembelajaran blended learning dengan kreativitas mahasiswa yang menerpakan pembelajaran langsung. Pembelajaran pada mata kuliah P2M2K dengan bantuan blended learning yaitu SIPDA Unimed terbukti secara empiris dapat berpengaruh terhadap kemampuan kreativitas mahasiswa. Hasil tersebut didukung dari pengujian secara inferensial dan deskriptif.

Berdasarkan pengujian dari hasil postes di atas, dapat disimpulkan bahwa strategi blended learning berbantuan SIPDA Unimed memberikan pengaruh yang signifikan terhadap kreativitas mahasiswa. Kesimpulan penelitian ini didukung oleh pendapat Darmono \& Maryam (2019) yang menyatakan bahwa pada tahapan pembelajaran dengan e-learning mahasiswa dituntut untuk dapat 
berperan aktif dalam memperoleh pengetahuannya sendiri sehingga mendapatkan pemahaman yang lebih mendalam. Melalui pembelajaran dengan strategi blended learning mahasiswa dapat mengunduh materi pelajaran kapan saja dan di mana saja (Ariyanto, Aditya \& Dwijayanti, 2019). Dosen sebagai fasilitator dapat mengunggah materi maupun tambahan materi kapan saja tanpa terbatas oleh ruang dan waktu, sehingga pembelajaran dapat berlangsung setiap saat dan mahasiswa dituntut untuk dapat belajar mandiri tidak lagi berpusat pada dosen. Dengan e-learning mahasiswa dapat membiasakan membangun sendiri pengetahuannya sehingga materi terserap dengan baik, membangun karakter saling menolong antar teman yang mengalami kesulitan belajar, serta pemanfaatan waktu yang lebih optimal. Hasil penelitian ini juga mendukung penelitian Samuel (dalam Gomez, 2007) yang menyatakan bahwa kreativitas bukanlah datang dengan mudah melalui bakat alami seseorang, melainkan melalui suatu usaha dan waktu dengan melibatkan pengalaman terkait kreativitas dalam suatu project.

Selain pemberian materi, dosen memanfaatkan e-learning untuk pemberian tugas. Tugas dikerjakan mahasiswa di rumah dan dipresentasikan ketika pembelajaran tatap muka dengan dosen. Dengan adanya e-learning tugas mahasiswa jadi lebih variatif dan kreatif karena banyaknya sumber belajar yang dapat dimanfaatkan baik melalui buku maupun secara online, sehingga memiliki referensi yang luas (Riwayati \& Destania, 2019). Mahasiswa juga dapat menggunakan aplikasi SIPDA Unimed untuk membantu dalam pengerjaan tugas yang diberikan. Temuan tersebut memperkuat hasil penelitian Kramarski \& Zeichner (2001) yang menyatakan bahwa pembelajaran dengan memanfaatkan teknologi memberikan dampak yang lebih luas dalam pembelajaran matematika, sehingga pembelajaran matematika lebih efektif. Selain itu, melalui penerapan pembelajaran yang memanfaatkan teknologi, mahasiswa dapat mengatur apa yang menjadi hal utama dan tanggung jawab baginya (Kramarski \& Zeichner, 2001).

Pada pembelajaran langsung yang terjadi adalah kebalikannya, mahasiswa hanya mempunyai sedikit informasi pengait terhadap informasi baru yang mereka peroleh. Mereka hanya mendapatkan penjelasan di dalam kelas. Kegiatan mahasiswa hanya mendengarkan penjelasan dan mencatat materi yang disampaikan oleh dosen. Ketika mereka ditanya materi pada pertemuan sebelumnya maka sebagian besar mahasiswa lupa. Walaupun pada beberapa penelitian menyatakan bahwa pembelajaran langsung dapat meningkatkan hasil belajar peserta didik (Al-Makahleh, 2011), tetapi tidak dengan kreativitas mahasiswa. Hal ini salah satunya dikarenakan pembelajaran langsung bersifat teacher-centered, sehingga kreativitas mahasiswa pun menjadi terbatas atau dapat dikatakan tidak berkembang. Padahal untuk mengembangkan kreativitas, tidak cukup hanya memberikan materi langsung kepada mahasiswa, tetapi haruslah memberikan ruang yang berisi bermacam pengalaman untuk merubah pengetahuannya (Abadzi et al., 2019). 


\section{KESIMPULAN}

Berdasarkan hasil penelitian dan pembahasan dapat disimpulkan bahwa strategi blended learning berbantuan SIPDA Unimed memberikan pengaruh yang signifikan terhadap kreativitas mahasiswa. Pembelajaran dengan strategi blended learning memerlukan waktu persiapan yang lama sehingga dosen perlu meluangkan banyak waktu untuk mempersiapkan materi untuk kegiatan online. Strategi blended learning dapat digunakan sebagai salah satu variasi dalam pembelajaran matematika, karena dengan menggunakan strategi pembelajaran ini mahasiswa dapat berpartisipasi aktif dalam pembelajaran, selain itu juga mampu mengembangkan kemampuan kreativitasnya.

\section{UCAPAN TERIMA KASIH}

Terima kasih penulis ucapkan kepada pihak Lembaga Penelitian dan Pengabdian Masyarakat Universitas Negeri Medan selaku pemberi dana untuk melakukan penelitian, sehingga penelitian ini dapat berjalan dengan baik. Semoga hasilnya dapat bermanfaat oleh semua pihak khususnya praktisi pendidikan.

\section{DAFTAR RUJUKAN}

Abadzi, H., Martelli, M., \& Primativo, S. (2019). Explorations of Creativity. 100.

Al-Makahleh, A. A. A. (2011). The Effect of Direct Instruction Strategy on Math Achievement of Primary 4th and 5th Grade Students with Learning Difficulties. International Education Studies, 4(4), 199-205.

Ariyanto, L., Aditya, D., \& Dwijayanti, I. (2019). Pengembangan Android Apps Berbasis Discovery Learning Untuk Meningkatkan Pemahaman Konsep Matematis Siswa Kelas VII. Edumatika: Jurnal Riset Pendidikan Matematika, 2(1), 40-51. doi:10.32939/ejrpm.v2i1.355

Budiarti, Y. (2015). Pengembangan Kemampuan Kreativitas dalam Pembelajaran IPS. Jurnal Promosi 3(1), 61-72.

Darmono, P. B., \& Maryam, I. (2019, February). Pengaruh Blended Learning Berbantuan Microsoft Mathematic Terhadap Kemampuan Berpikir Kritis Mahasiswa. In PRISMA, Prosiding Seminar Nasional Matematika, 583-588.

Gomez, J. G. (2007). What Do We Know about Creativity? Journal of Effective Teaching, 7(1), 31-43.

Kramarski, B., \& Zeichner, O. (2001). Using Technology to Enhance Mathematical Reasoning: Effects of Feedback and Self-Regulation Learning. Educational Media International, 38(2/3), 77-82.

Riwayati, S., \& Destania, Y. (2019). Efektifitas Desain Lembar Kerja Mahasiswa Terintegrasi Internet untuk Mengembangkan Kemampuan Penalaran Matematis Mahasiswa. Edumatika: Jurnal Riset Pendidikan Matematika, 2(2), 104-112. doi:10.32939/ejrpm.v2i2.409

Saparahayuningsih, S. (2010). Peningkatan Kecerdasan dan Kreativitas Siswa. Jurnal Kreatif: Jurnal Kependidikan Dasar 1(1), 1-6.

Schwab, K. (n.d.). The Global Competitiveness Report. 400.

Soleymanpour, J. (2014). The Effects of Creative Teaching Method on Motivation and Academic Achievement of Elementary School Students in Academic Year 2014-2015. Singaporean Journal of Business, Economics and Management Studies, 51(1812), 1-5.

Thorne, K. (2003). Blended Learning: How to Integrate Online and Traditional Learning. Kogan Page Publishers. 
Ulandari, N., Putri, R., Ningsih, F., \& Putra, A. (2019). Efektivitas Model Pembelajaran Inquiry terhadap Kemampuan Berpikir Kreatif Siswa pada Materi Teorema Pythagoras. Jurnal Cendekia: Jurnal Pendidikan Matematika, 3(2), 227-237.

Wahyudi, W., \& Winanto, A. (2018). Development of Project-based Blended Learning (PjB2L) Model To Increase Pre-Service Primary Teacher Creativity. Journal of Educational Science and Technology (EST), 4(2), 91-102. 